\title{
LOYALTY PROGRAMS EFFECTIVENESS
}

\author{
Katarzyna SZCZEPAŃSKA*, Patryk GAWRON \\ *Faculty of Management \\ Warsaw University of Technology, Warsaw, Poland \\ e-mail: k.szczepanska@wz.pw.edu.pl
}

\begin{abstract}
An increasing number of loyalty programs is one of the most common phenomena observed in the practice of marketing companies on the market today. Objectives and tasks of loyalty programs determine the type of use of marketing instruments affecting the attitudes and behaviours of customers, which is aimed at the program. The diversity of factors influencing the effectiveness of loyalty programs should set the scope and object of empirical research. As the results of studies to evaluate the effectiveness of loyalty programs mainly on the $\mathrm{B} 2 \mathrm{C}$ market is diverse in terms of the criteria. This article presents the essence of loyalty programs and the factors influencing their effectiveness.
\end{abstract}

Keywords: loyalty program, customer loyalty, factors for the effectiveness of loyalty program.

Development of loyalty programs

Visible and dynamic development of loyalty programs reflects the increasing prevalence of relationship marketing philosophy in current business practice. Moreover, discussed phenomenon also reflects a host of vibrant changes that take place in global business arena and can be exemplified by the following trends discussed in numerous research studies:

- observed increasing competitiveness of various markets,

- increasing market awareness demonstrated by customers and escalating customers' expectations,

- decreasing homogeneity of existing customer groups.

Dynamic increase in the numbers of customers that willingly participate in various loyalty programs clearly suggests that such programs in the recent years have been steadily developing and have been widely accepted in the global marketplace. "Between 2000 and 2006 the number of North American customers that participated in various loyalty programs increased by $35,5 \%$ and reached unprecedented 1,5 billion" (Ferguson et al. [9], p. 1).

Moreover, increasing popularity of loyalty programs resulted in common acceptance of a thesis, which states that "the implementation of loyalty program by a modern business enterprise is not motivated by the enterprise's drive to strengthen and develop relationships with its key customers. The implementation of discussed marketing tool is inevitable in a market, where all direct competitors invite customers to participate in their own loyalty programs and where inability and unwillingness to introduce similar tools might lead to significant defections in existing customer base." (Ferguson et al. [9], p. 2; Meyer-Waarden et al. [24], pp. 72).

Current loyalty programs are largely based on Advantage Programme, the first fully functional loyalty scheme implemented by American Airlines in 1981. In this initiative, American Airlines customers were invited to collect virtual air miles, which later could be redeemed for free flights. Historical development of loyalty schemes in different sectors of global economy is illustrated in Fig.1.

Currently loyalty programs are mostly implemented by companies from global economy sectors. It is estimated that in the world's most developed markets, more than half adult population is enrolled in at least one loyalty program (Kivetz [11], p. 726).

The development of loyalty programs they apply to the following types (Rudawska [25], pp. 100-103):

- marketing clubs,

- loyalty cards,

- reward loyalty programs,

- participation programs (programs continued). 


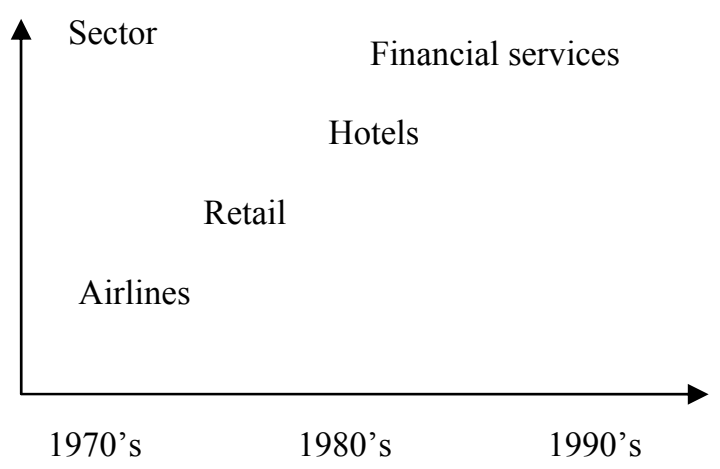

Figure 1. Historical development of loyalty schemes (source: own work)

According to the criterion of the form of a loyalty program is distinguished by the following types (Kwiatek et al. [16], pp. 323-324):

1) programs based on the idea of participation (clubs):

a) pure clubs:

- based on a loyalty card (card recognition) that provides a discount when purchasing products or services provided by the company organizing the club,

- based on the added value of the brand,

- operating on the basis of membership fee,

b) mixed clubs:

- focus on ideas, not on the particular brand,

- focus on brand and partners of the club;

2) programs based on the idea of collecting:

c) based on the traditional technique,

d) based on electronic technology.

Increasing popularity of loyalty programs can be explained by observed changes in today's marketplace, where the customer enjoys unprecedented freedom to choose from a wide variety of suppliers of seemingly homogenous goods. Such market is characterised by a large number of competitors offering marginally different goods and fighting for the attention of similar customers. Described market circumstances place previously underappreciated consumer in a new, privileged position and create a set of previously unidentified challenges for any business striving to develop and strengthen relationships with its most valued buyers.

Based on presented arguments it can be concluded, that today's customers relatively seldom declare their willingness to form lasting relationships with any goods and services provider who fails to present them with a host of attractive incentives. Such conclusion may explain why loyalty programs, have currently been viewed as a key marketing tool, which promotes and drives customer relationship building. Moreover, while implementation of loyalty programs inevitably generates certain amount of costs, ultimately it should lead to increased turnover and strengthened profitability of a business enterprise. Well - devised and properly operated loyalty program is one of the main competitor's factors that may differentiate a company from its direct competitors.

Developments in information technology facilitates the management of loyalty programs, implementation of which leads to the maintenance of existing customers and acquire new, changing their purchasing preferences and to increase sales. The software makes it easy to carry out marketing activities in the following areas:

- definition of loyalty programs - setting the rules for their activities, methods to reach customers and to participate in the program,

- transactions loyalty - the award credits calculation or rebates based on purchases made or enforcement actions by the customer bonus,

- to collect marketing information about customers' habits - the ability to track customer response to the action undertaken,

- marketing and management actions to carry out their analysis - the possibility of defining marketing campaigns and run them directly through the results,

- creation of a sustainable relationship with customers - using the contact center and customer portal as a form of maintaining communication with the customer,

- marketing strategy - including a loyalty program to the overall strategy for the company. 


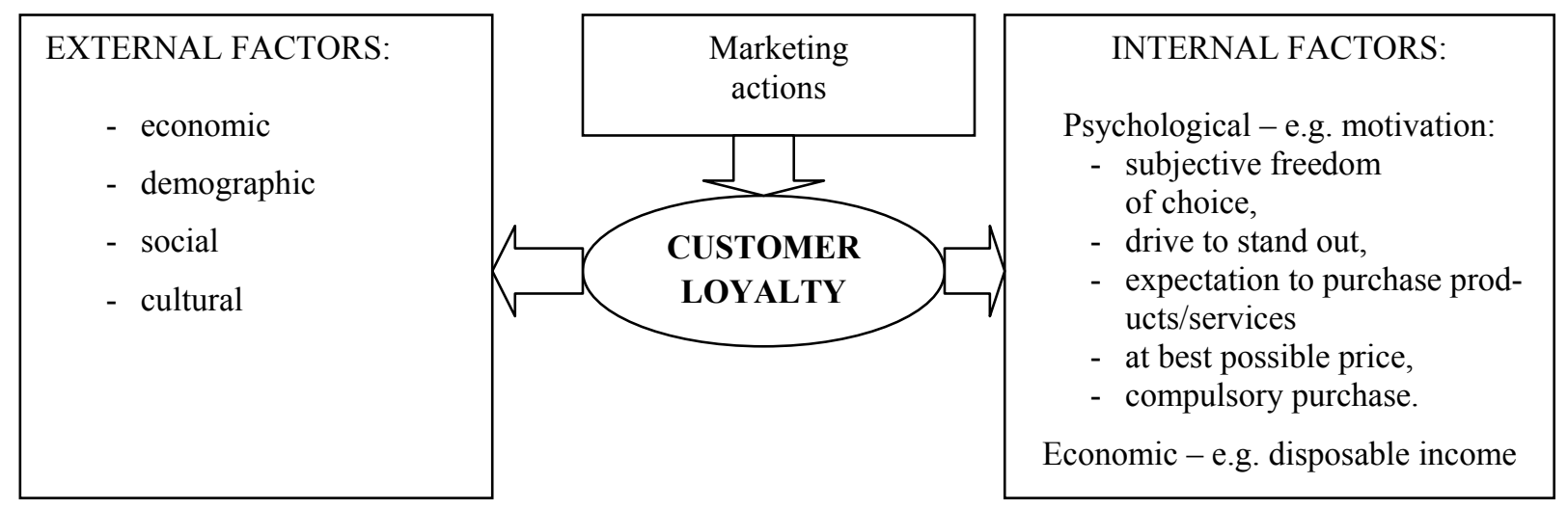

Figure 2: Factors of customer loyalty (source: own work)

Moreover, a robust loyalty programs usually weakens customers' drive to switch goods and services provider, and therefore increases company's competitive advantage over its closest market rivals. In conclusion, to presented deliberations on the nature of current, dynamic development of loyalty programs, it must be stressed that any implemented, they should lead to increased volume of business as well as other, unquantifiable benefits, which viewed and analysed together will form the very basis for the assessment of loyalty program efficiency.

\section{Customer loyalty}

From viewpoint of praxeology, customer loyalty can be defined as a constant and positive attitude towards an object (i.e. brand or business enterprise). Marketing definition of loyalty traditionally covered two aspects of the phenomenon: behavioural aspect and attitudinal aspect. Behavioural loyalty explained customers' actions, which included repeat purchases, their proneness to be attracted by competitors' marketing efforts as well as their willingness to engage in word - ofmouth marketing.

Without a doubt, the classic approach to customer loyalty ignored factors affecting the attitudes and behaviour and does not include themes of loyalty. Taking into account categories such as income or lack of alternatives to choose from, we can say that the nature of economic factors determine the customer loyalty. If, however, will be included in the analysis of the determinants of market, demographic, or cultural, it reveals a broad context for consideration of the factors influencing and shaping the loyalty of company's customers.
Based on presented discussion, one must question the validity of loyalty whenever displayed loyal behaviour (i.e. repeat purchase) stems from barriers imposed by the goods provider, such as any limitations included in business contract. Customers' passive attitude caused by objective (e.g. transaction characteristics) as well as subjective (e.g. customer's indifference) factors teamed up with their repeat purchases inevitably leads to a conclusion that such scenario may not be perceived as one exemplifying loyalty. So, it seems clear that in order to discuss loyalty we must take into account a certain degree of emotional engagement displayed by a customer.

On the one hand, such statement highlights the need to examine the levels of emotional engagement displayed by customers. On the other hand, voiced need to examine customers' emotional engagement widens the scope of any discussion on loyalty as well as any marketing activity designed and implemented by a business enterprise. Any discussion on loyalty cannot fail to include careful examination of customer satisfaction levels, which are shaped by customer's subjective evaluation of purchased product/service, received value, and overall interaction with a company. The structure of the generic factors that shape customer loyalty presented in Fig. 2.

Wide variety of factors affecting customer loyalty makes it nearly impossible to present a straightforward and complete definition of the discussed term. Any inconsistencies, in the meaning of loyalty should be clarified by the overview of accepted definitions of the term presented in the following table (see Table 1). 
Table 1. Overview of customer loyalty definitions

(source: own study based on Urban et al. [30], pp. 11-14; [33];

Bloemer et al. [3], pp. 499-513)

\begin{tabular}{|c|c|}
\hline Author & Definition \\
\hline The Global Loyalty Agency & $\begin{array}{l}\text { all the feelings or experiences that would incline a customer } \\
\text { to consider the re-purchase of a particular product, service or brand } \\
\text { or re-visit particular company, shop or website }\end{array}$ \\
\hline Newnan J.W., Werbel R.A. & $\begin{array}{l}\text { repeat purchase of a particular brand, without considering purchase } \\
\text { of any other available brand }\end{array}$ \\
\hline $\begin{array}{l}\text { Jacoby J., Chestnut R.W., } \\
\text { Day G.S. }\end{array}$ & $\begin{array}{l}\text { customer's predisposition towards the brand as a function } \\
\text { of psychological processes }\end{array}$ \\
\hline Storbacka K., Lehtinen J.R. & intention to act and willingness to interact with others \\
\hline Bloemer J., de Ruyter K. & $\begin{array}{l}\text { customers' non-incidental and intentional actions displayed over } \\
\text { a long period of time towards a particular service/product supplier } \\
\text { which operates among numerous and similar service/product } \\
\text { suppliers }\end{array}$ \\
\hline Olivier R.L. & $\begin{array}{l}\text { deeply-term engagement and product/service/brand re-purchase } \\
\text { intention displayed toward a particular product, service or brand }\end{array}$ \\
\hline Reichheld F.F. & $\begin{array}{l}\text { willingness to invest in further product/service/brand relationship } \\
\text { development }\end{array}$ \\
\hline Dick A.S., Basu K. & Function of attitude manifested in behaviour \\
\hline Zawadzka A.M. & $\begin{array}{l}\text { the result of rational-functional motivation teamed up } \\
\text { with emotional-symbolic motivation }\end{array}$ \\
\hline
\end{tabular}

As shown in the loyalty definitions overview, most academic discussions on the topic take into account behavioural and psychological loyalty drivers. As a result, for a considerable period of time loyalty was predominately perceived as a regular re-patronage or re-purchase driven by intentional, premeditated customer's actions and accompanied by positive attitude. Consequently, most presented loyalty definitions were drawn on the assumption that two main sets of loyalty drivers (i.e. behavioural and psychological drivers) should be analysed separately and independently, without the need to examine any correlations existing be- tween discussed drivers. Nevertheless, it is evident that such correlations should be taken into account and closely examined, which may help with critical classification of existing loyalty definitions (see Table 2). The examination of those correlations allows for identification of new loyalty drivers (i.e.: action based, follow - up) which always remain closely linked and intertwined. It should be noted that the classifications omit reference to specific markets (B2B, B2G). Moreover, in varying degrees, refer to the types of objects that are the subject of loyalty (product category, personnel, place of purchase, brand and organization).

Table 2. Loyalty drivers and definitions

(source: own study based on Garbarski et al. [10], pp. 347-348; Urban et al. [30], p. 12; Rudawska [25] p. 27; Dębski [5], p. 40)

\begin{tabular}{|c|l|}
\hline Driver & \multicolumn{1}{c|}{ Definition } \\
\hline \multirow{4}{*}{ Psychological } & high level of emotional attachment to company's employees, products or services \\
\cline { 2 - 2 } & combined role of psychological processes \\
\cline { 2 - 2 } & \begin{tabular}{l} 
intention to act and willingness to engage with others \\
\cline { 2 - 2 } Action - based \\
vourable circumstances
\end{tabular} \\
\hline \multirow{3}{*}{ Follow - up } & $\begin{array}{l}\text { systematic, intentional repurchase of a specific product/service/brand accompanied } \\
\text { by strong conviction that selected product/service/brand is superior to other availa- } \\
\text { ble options }\end{array}$ \\
\hline $\begin{array}{l}\text { the result of customers' learning process, which confirms that selected prod- } \\
\text { uct/service/brand fulfils their needs and meets their expectations to a far greater } \\
\text { extent than any other available product/service/brand (brings a unique and desired } \\
\text { benefits) }\end{array}$ \\
\hline
\end{tabular}


Most available literature on the discussed subject matter tends to focus on brand loyalty in $\mathrm{B} 2 \mathrm{C}$ markets. As demonstrated in extensive research studies (Falkowski, et al. [8], p. 307):

- there is correlation between the levels of perceived satisfaction and brand loyalty (only satisfied customers declared brand loyalty),

- brand loyal customers do not always declare complete contentment with their purchase,

- satisfied customers generally declare a certain level of brand loyalty.

Those findings seem to justify why customer loyalty is often categorized based on customers' brand awareness, where brand awareness is perceived as one of key loyalty drivers. The concept of customer loyalty, particularly in marketing value, is important because to the fact that it favours formation of a combination of (Dobiegała-Korona et al. [6], pp. 225-226):

- quality (close to $0 \%$ defects),

- compliance with the expectations (close to $0 \%$ deviation),

- reliability (close to $0 \%$ failure),

- sustainability (close lifetime warranty),

- easy to maintain (cheap, fast repair),

- diagnostics (the easy identification of the customer),

- accessibility (close to $100 \%$ ),

- technical features (latest technology),

- functional characteristics (colour, style, product environmentally friendly),

- a value - added properties (full safety of the product),

- future needs (the need to participate in improving the product),

- operational effectiveness,

- pre - sales services (communication, cooperation),

- after - sales services (maintenance of client contact and interest),

- delivery (in the short term, the installation of the product),

- price (less than the price competition),

- resale value (a large percentage of the purchase price),

- reputation (perceived value),

- cooperation (accountability, flexibility, sensitivity to the needs of customers, kindness),
- communication (listening skills, ease of contact, can leave feedback).

Presented discussion confirms high levels of complexity and ambiguity of customer loyalty. It seems that this very complexity makes it extremely difficult to draw a straightforward and comprehensive definition of the discussed term. The multitude of existing definitions of customer loyalty can be explained by growing heterogeneity of various markets as well as increasing range of internal and external factors affecting both, buyers and suppliers. Market characteristics (subjective, objective) and its broad determinants justify both the multiplicity and extent of use of the concept of customer loyalty.

\section{The essence of loyalty program}

A loyalty program should be viewed as a marketing tool, which helps to achieve general aims of accepted marketing strategy and leads to strengthened relationships with customers, as a part of customer relationship managements plan developed by an enterprise. Therefore, a loyalty scheme can be defined as a "long-term marketing initiative which allows all regular customers to collect virtual points awarded after each repeat purchase, which later can be redeemed for free products, gifts, discounts and other forms of material rewards" (Liu [21], p. 21). Described loyalty scheme is commonly applied across B2C markets but as demonstrated by extensive research studies can be utilized equally successfully across large-scale B2B markets (one of numerous examples of loyalty initiatives observed in B2B markets are customised web-based platforms which help companies to serve their most valued and profitable buyers). Therefore, it can be concluded, that any activity undertaken by an enterprise (regardless of its market size and characteristics) which aims at rewarding its customers for repeat patronage may be perceived as a loyalty program.

The main behavioural purpose of any loyalty initiative is to maximize the level of customer's relative attachment toward their favourite products or services. Such purpose is realized, through implementation of well devised set of marketing tools, which collectively form a company's loyalty scheme. Apart from their behavioural aspects, all loyalty programs are implemented in order to achieve a set of financial and economic aims, i.e.: reduce operational costs of dealing with cus- 
tomers, increase overall sales volume and profitability, and maximize the value of customer portfolio.

Regardless of the market category (B2C, B2B), implementation and utilization of a well - devised loyalty program ultimately leads to strengthened relationships with existing customers, which in turn allows a company to collect a host of previously unavailable data that can be used to improve or redesign existing loyalty tools and other marketing initiatives (e.g. re - segmentation). Therefore, it can be concluded, that operating a loyalty scheme not only improves customer relationship building capabilities of an enterprise, but also improves customer intelligence and allows for better customer information management.

Customer intelligence obtained in the process of loyalty scheme operation is also useful in "improving the perceived value of goods and services offered by an enterprise" (Bolton et al. [4], p. 98; Yi et al. [34], p. 233). Overall improvement in the appeal of goods and services offered by a company inevitably leads to improved perception of the value of such goods and services. Discussed maximization of value is one of the core conditions that allow for "initiation of a relation with a customer and form the basis for further, mutually beneficial relationship between a company and its consumers" (Sirdeshmukh et al. [28], p. 18; Woodruff [32], p. 142). The main aims and purposes of any loyalty program are as follows:

- effective ecouragmenet of repeat patronage (repurchase behaviour),

- increased customer's relative attachement to company's offer, company's values and company's image,

- increased interactions and improved dialogue with exisiting customers,

- improved customer intelligence,

- improved long - term cooperation capabilities of an enterprise.

Considering the outlined purposes of any loyalty scheme, such initiatives should always aim to develop and strenghten both: attitudinal and behavioural customer loyalty. Loyalty program increases overall value perception of doing business with the firm in two complementary stages. The first stage of value enhancements is based on awarding customers with a specific number of virtual points in exchange for their repeat purchase. Over time, customers develop internal drive to collect more virtual points and develop "positive attitude towards preferred goods or services provider. In turn, positive attitude toward preferred goods or services provider strengthens the relationship between a firm and its customers, and consequently increases the levels of customers' behavioural and attitudinal loyalty" (Lemon et al. [19], p. 4). The number of points collected over a period of time acts as a psychological incentive, which drives the customers to repeat their purchases with preferred company. Subjectively perceived degrees of motivation to repurchase a set of goods or services, are usually defined, by the relative value of collected points (i.e. the number of points needed to claim a reward). Therefore it can be concluded, that in the case of point-based loyalty schemes, the relative value of awarded points has a direct effect on the levels of loyalty declared by a customer.

The second stage of value enhancement process begins whenever a customer decides to redeem collected virtual points for material rewards. "The free reward functions as a positive reinforcement of consumers' purchase behaviour and conditions them to continue doing business with the firm" (Sheth et al. [26], p. 263). Psychologically, giving free rewards to customers shows the firm's appreciation and personal recognition of its customers. Current loyalty programs are therefore aimed, at deepening consumer's relationship with a firm over a long period, which should result in decreased customer churn, decreased costs of customer service, decreased advertising expenditure. This set of results expected from any loyalty programs are what differentiates a loyalty scheme from marketing tools associated with broadly perceived sales promotion (i.e. rewarding customers for incidental purchase of a specific product or service).

Extensive research into loyalty programs in B2C markets confirms that company's operate two main types of discussed initiatives: program - centric loyalty schemes and customer - centric loyalty schemes. Based on that research we can clearly identify the main changes in loyalty programs that have been observed over time. 
Table 3. Types of loyalty programs

(based on: Kumar [14], p. 326)

\begin{tabular}{|l|l|}
\hline \multicolumn{1}{|c|}{ Types of loyalty programs } \\
\hline \multicolumn{1}{|c|}{ Program - centric } & \multicolumn{1}{c|}{ Customer - centric } \\
\hline Operational level - aggregate & Operational level - customer \\
\hline $\begin{array}{l}\text { Standardized program, based on usage } \\
\text { or spending }\end{array}$ & $\begin{array}{l}\text { Customized program, based on types of usage or type } \\
\text { of spending }\end{array}$ \\
\hline $\begin{array}{l}\text { Standard and uniform reward scheme, } \\
\text { aimed at repeat purchase }\end{array}$ & $\begin{array}{l}\text { Personalized reward scheme, aimed at influencing } \\
\text { specific behavioural change or attitudinal gratification }\end{array}$ \\
\hline $\begin{array}{l}\text { Minimal reward options } \\
\text { Reactive reward mechanism }\end{array}$ & Multiple reward options \\
\hline $\begin{array}{l}\text { Tangible rewards } \\
\text { and revenues, build behavioural loyalty } \\
\text { through repeat purchase or usage }\end{array}$ & $\begin{array}{l}\text { Program objective: link loyalty to profitability, influence } \\
\text { behavioural loyalty, cultivate attitudinal loyalty }\end{array}$ \\
\hline Metrics used: RFM, PCV, SOW & Tangible and experiential rewards \\
\hline Technology and analytics usage: minimal & Technology and analytics usage: extensive \\
\hline
\end{tabular}

The historical changes in loyalty initiatives can be followed within the set of dimensions, outlined below:

- operational level,

- program objective,

- program type,

- rewarding scheme and reward options,

- reward mechanism,

- reward type,

- metrics used,

- technology and analytics usage.

Changes in loyalty programs by criteria: operational level, the program rewards scheme, options and a mechanism for rewarding, rewards, objective indicators, the use of information technology are presented in Table 3. Introduction of loyalty programs is generally aimed, at achieving several key objectives, which fall into three main categories:

- maximization of value for customers, offering value that matches customers' expectations,
- enhancement of relationships that bond a customers with a firm,

- fulfilling loyalty program's commitments and promises.

Based on the main objectives of any loyalty program outlined above it can be concluded, that the firm's ability to maximise the value for customers with the information obtained via loyalty scheme introduction is one of the key elements that define the efficiency of loyalty initiatives from both: a customer's as well as a firm's perspectives.

\section{$4 \quad$ Loyalty program tools}

Depending on the degree of customer loyalty is generally applicable to change forms of their reward. An example of the relationship between forms of reward and the level of customer loyalty is shown in Fig. 3. 


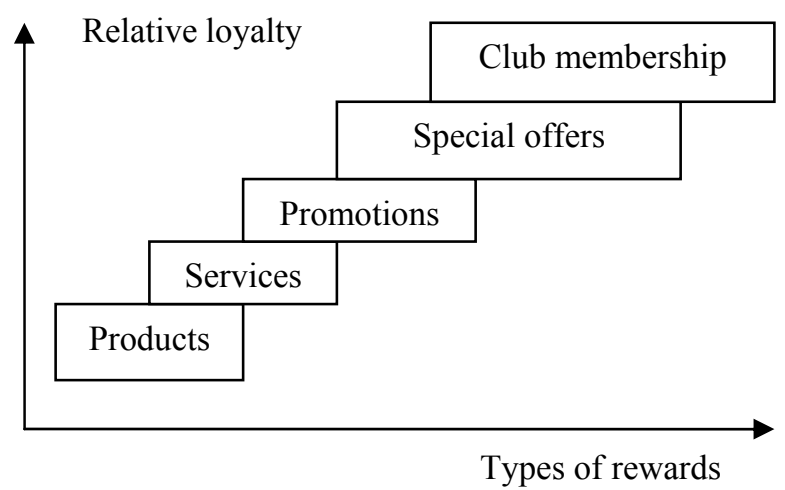

Figure 3. Observed relationship between types of rewards and levels of relative loyalty (source: own work)

As can be seen from studies on the Polish market, B2C loyalty programs used only $51 \%$ of the surveyed companies. The most common used instruments are (www.rolandberger.com):

- bonus programs (53\%) - the program offers a collection of points in exchange for using or acquiring company's products and their subsequent conversion to the prize,

- customer card (21\%) - discount card loyalty that allows access to additional services,

- customer clubs (18\%) - regular customers, which offers additional services (for membership of the club determines the size of their purchases and customer seniority),

- couponing ( $8 \%$ of respondents) - the transfer of vouchers enabling customers to purchase goods at a reduced price or free of charge under certain conditions of purchase.

The necessity to award loyal behaviour with tangible rewards is clearly justified by research, which shows, that levels of loyalty declared by customers tend to fluctuate over time. "Customers' buying behaviour is shaped by (...) a set of behavioural drivers, which affect the customers with various intensity. Customer's will to develop loyalty toward a brand is directly linked to the intensity of behavioural drivers, which the customer is exposed to" (Urban et al. [30], p. 70). Based on those findings we can outline the following key loyalty drivers:

- relationship drivers (e.g.: customer - company relationship, customer's emotional involvement with a company, etc.),
- social drivers (e.g.: customers' need to stand out from the crowd, etc.),

- value - based drivers (e.g.: most favourable value price ratio, etc),

- external drivers (lack of alternative suppliers due to significant market barriers, etc.).

Therefore, the dynamic nature of customer loyalty justifies the need to shape the tools utilized by a loyalty scheme in accordance with the behaviour and attitudes exhibited by a targeted customer group. From a psychological viewpoint, providing the customers with free rewards for their repeat patronage validates a company's goodwill and emphasizes a company's positive attitude towards its customers. Upon receipt of a free reward, a customer feels important and valued by a firm and is therefore more likely to continue his relationship with a favourite goods or services provider. As shown by extensive research, rewarding customers for repeat patronage serves two important purposes:

- provides customers with free-of-charge access to sought-after goods and services, which are often perceived as luxurious (Kivetz [11], p. 728),

- enhances customer engagement in a firm's everyday operations (Dowling et al. [7], p. 73), and therefore improves the relationships between customers and goods or services provider.

Results of research carried out in Europe and the U.S. support use, according to the criterion of time, two types of reward: immediate and deferred. The types of awards are presented in Table 4. 
Table 4: Types of rewards

(source: Kwiatek [15],p. 90)

\begin{tabular}{|l|c|c|c|}
\hline \multicolumn{1}{|c|}{ Specification } & $\begin{array}{c}\text { Immediate reduction } \\
\text { of prices (\%) }\end{array}$ & $\begin{array}{c}\text { Awards postponed } \\
(\%)\end{array}$ & $\begin{array}{c}\text { The electronic wallets } \\
(\%)\end{array}$ \\
\hline Retail Trade & 63 & 72 & 7 \\
\hline Services & 56 & 17 & 3 \\
\hline Total & 58 & 41 & 5 \\
\hline
\end{tabular}

Those findings further justify the need to shape loyalty - building tools in accordance with targeted customer group expectations, which in turn will result in enhanced levels of customer loyalty. Moreover, both tangible and intangible rewards claimed by the customers enrolled in a loyalty scheme create a feeling of excitement among consumers, which should improve firm's overall image and enhance the perceived value of a company's offer. It is also worth noting, that discussed loyalty program tools may fulfil various objectives, which are outlined below:

- sales improvement objective - increased sales volume, increased sales value,

- data collection objective - estimation of repeat purchase probability,

- psychological objective - enhancement of a firm's image, relationship building,

- market objective - competitive advantage improvement,

- economic objective - efficiency valuation, sales profitability estimation.

Moreover, careful analysis of the relationship between individual loyalty scheme tools and the way they affect customer behaviour, seem to be at the very core estimation of the overall loyalty program effectiveness. Such exercise may involve path analysis studies, a statistical method of finding cause and effect relationships, which allow a description of the dependencies among a set of variables.

\section{$5 \quad$ Factors affecting loyalty program effectiveness}

Loyalty program effectiveness is defined by the degree with which a scheme fulfils a set of clearly outlined objectives. Each program may have its own unique set of success measures depending on its intended objectives, which complicates an unbiased assessment of scheme effectiveness, especially in highly competi- tive markets. Many of today's customers take advantage of numerous loyalty programs, often provided by company, which are in direct competition. Therefore,

it can be assumed, that loyalty scheme success depends not only on the program itself but also on other facilitating and inhibiting factors present in a company's internal and external environment. Program - related factors, which explain a company's internal strategies that can contribute to the success of loyalty scheme, include the following:

- program participation requirements (convenience of participation, cost of participation),

- program point structure (point issuance and point collection convenience),

- program reward structure (points value, variety of reward options, choice and availability of rewards, brand - reward congruence, reward form: cash versus free products),

- program management (capturing and analysing consumer intelligence, organizational support, position of loyalty program in a firm's overall marketing strategy).

Success factors that are present in a firm's external environment, and therefore cannot be fully controlled include the following:

- consumers' needs and expectations (consumer's usage levels, consumer's need to stand out, etc.),

- consumers' generic traits and characteristics (demographics, current and expected shopping orientation, variety seeking, price sensitivity),

- competitive environment characteristics (firm's market position, product sustainability and expandability, market segmentation),

- competitive loyalty programs characteristics (loyalty program saturation, loyalty program differentiation, loyalty program awareness). 


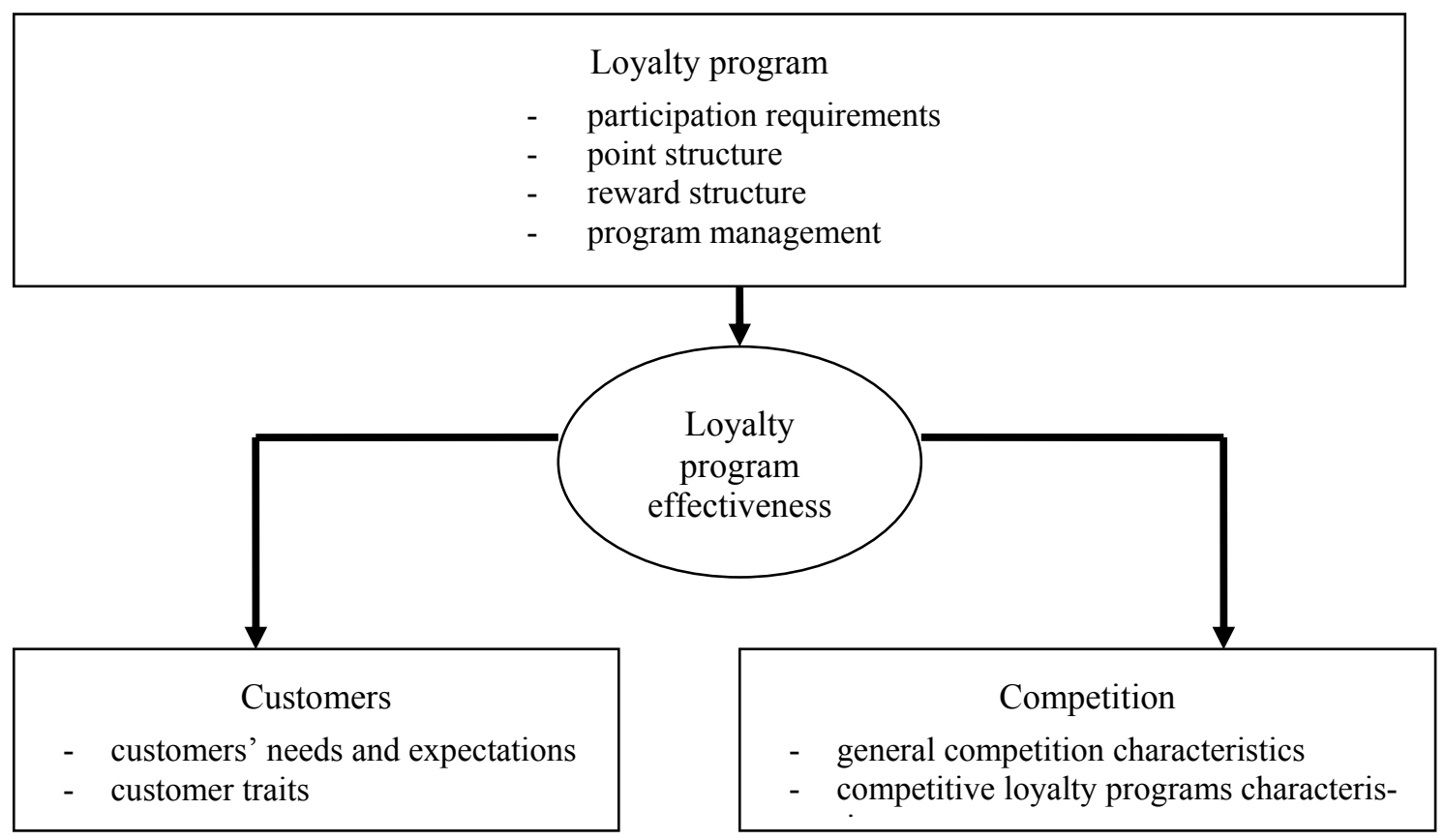

Figure 4. Factors affecting loyalty program effectiveness (source: own work based on: Liu et al. [22], p. 95)

Results of research on the Polish market $\mathrm{B} 2 \mathrm{C}$ show that the main causes of failure in loyalty programs include (www.rolandberger.com):

- lack of involvement in the program of all departments,

- too few rewards for program participants,

- slow implementation of promised benefits (awards, services, privileges),

- too complicated way of communicating about the program,

- expectation of immediate benefits from the program.

Key factors affecting loyalty program effectiveness are illustrated in Fig. 4.

As shown in Fig. 4, a loyalty program should be devised based on all, available information on a firm's external environment. Each element of such program must account for the dynamic nature of the environment and make best possible use of all the available data on existing loyalty programs (especially programs offered by a firm's direct competition). Process of preparation loyalty program must also make use of detailed consumer data, which can be obtained from existing, consumer database.

\section{$6 \quad$ Research on loyalty program effectiveness}

Loyalty program effectiveness defined by the degree with which a scheme fulfils a set of clearly outlined objectives depends largely on proper customization of all program's elements. Effectiveness of customer centric schemes as well as program - oriented schemes can be considered from two independent perspectives:

- short - term effects of the scheme on consumers' repurchase behaviour and their attitudes towards firm's products,

- long - term effects of the scheme on consumers' buying behaviour and their attitudes towards firm's products.

Moreover, for each group of factors identified as affecting customer loyalty, a firm should devise an appropriate set of measures, which will enable correct assessment of loyalty - related marketing activity effectiveness. A set of properly devised analytical measures of loyalty program effectiveness allows identification of all scheme's attributes, which are likely to be strongly affected by any changes that take place in a firm's external environment.

Moreover, regular use of such measures enables collection of most suitable consumer data, which in turn can be used for ongoing loyalty scheme improvement. 
To improve existing loyalty programs, company should also conduct ongoing studies into customer responsiveness to current marketing activities, which will allow for better customization of all marketing tools devised for future implementation. Loyalty program effectiveness can also be assessed based on changes in existing customers' lifetime value (CLV). In the financial terms, customer lifetime value means "the difference between discounted future profit margin from a customer and total costs of generating the revenue, which can be calculated using the following formula" (Kołczyński [12], p. 369):

$$
\operatorname{CLV}=\left[\sum\left(\mathrm{M}_{\mathrm{a}}-\mathrm{K}_{\mathrm{a}}\right) \mathrm{r}^{(\mathrm{a}-1)} /(1+\mathrm{i})^{\mathrm{a}}\right]-\mathrm{KP}
$$

where:

\section{CLV- Customer Lifetime Value,}

a - number of the successive customer activity period,

M - gross profit contribution per customer per period a,

$\mathrm{K}$ - customer service cost per customer per period a,

$\mathrm{R}$ - retention rate,

i - average forecasted interest rate,

KP - customer acquisition cost.

Customer lifetime value can also be calculated using net cash flow parameter (the difference between total revenue generated by a customer and total costs of customer acquisition, retention and relationship development) and discount rate parameter (e.g.: total cost of all activities aimed at a customer).

Financial efficiency of existing loyalty program can be measured with customer equity model, which fundamentally equals returns on acquisition plus returns on retention plus returns on add-on selling across a firm's entire customer portfolio over time (Blattberg [2], p. 201). Despite relatively common use of loyalty programs, there is limited evidence on the long-term financial and marketing effects of such programs and their effectiveness is not well established. Available research data, mainly from B2C markets, focuses on three key areas:

- comparison of loyalty programs across competitors (multiple company's),

- comparison of the behaviour of loyalty program members with that of non-members,

- studies of the loyalty program members' behaviour across time.
Research into loyalty programs run by major airlines showed significant short-term increase in the interest in airline offer across majority of program members (Kopalle et al. [13], p. 23). Comparison studies of loyalty program members and non - members behaviour among customers of North American and European financial institutions conducted in 2000 and 2003 (Bolton et al. [4], p. 95; Verhoef [31], p. 32) suggest that participation in a firm's loyalty program makes consumers likely to stay with the firm and encourages them to expand their business with the company. The same studies also find that program members weigh negative experience less in their re - patronage decisions than non - members, which is consistent with the proposition that loyalty programs allow company to enjoy their customers more exclusively and are less likely to experience significant customer churn due to customer's negative experiences. On the other hand, discussed studies do not find significant main effect of loyalty program membership on long-term customer retention.

It is also worth noting that a large number of studies suggest that loyalty programs have minimal or no impact on consumer's loyalty behaviour. Those studies are based on assumption that the increase of re- patronage rate does not stem from consumer loyalty and loyalty development techniques implemented by company but rather from consumers' generic traits. Furthermore, discussed studies divide all consumers into two major groups (Lewis [20], p. 283; Verhoef [31], p. 32):

- consumers reluctant or unwilling to switch suppliers,

- consumers who actively search for most favourable offer and are indifferent to loyalty - building tools implemented by suppliers.

Studies of the loyalty program members' behaviour across time conducted in the retail sector support the positive impact of loyalty building tools on consumer's increased spending their re - patronage rates (Lal et al. [17], p. 180; Taylor et al. [29], p. 294). They do not support the hypothesis that such techniques help to develop significant bonds between consumers and brands (i.e. loyalty).

Discussed studies suggest that loyalty program members exhibit loyalty toward the program itself, mainly due to potential rewards offered by the scheme and do not declare significant loyalty toward a firm or a brand. 
Table 5. Results of loyalty programs

(source: own work based on: Kwiatek [15], pp. 95-99)

\begin{tabular}{|c|c|}
\hline Company & Results \\
\hline Lisner & $\begin{array}{l}\text { - exceeded the expected value quantitative objectives, } \\
\text { - there has been the effect of so - called full shelves before beginning } \\
\text { of television campaign. }\end{array}$ \\
\hline Amica & $\begin{array}{l}\text { - } \quad \text { enhancing the image, } \\
\text { - } \quad \text { establishing relationships with key market participants, } \\
\text { - } \quad \text { increased sales by } 15 \% \text { per annum, } \\
\text { - } \quad \text { increase in market share does not cause decrease in the value } \\
\text { of profitability ratios. }\end{array}$ \\
\hline
\end{tabular}

Researchers also identified temporary shock in spending as consumers increased their purchase levels to qualify for a reward; however, they also found that after the reward, was obtained the positive change in behaviour tended to dissipate.

Similar insignificant impact of loyalty programs, on true loyalty among consumers, was shown, in research studies conducted in 2005 among over 57 thousand US loyalties - card program members (Allaway et al. [1], p. 317). Extensive research also supports the hypothesis, that limited impact of loyalty programs on true loyalty among consumers results from overcrowding the market with homogenous (or nearly homogenous) loyalty-building schemes, which most frequently have been devised based on wrong assumptions regarding consumers' needs and expectations. On the other hand, a number of published studies confirm the positive effect of discussed initiatives on loyal attitudes among consumers, which are exhibited in their everyday spending patterns (e.g.: Lewis [20], p. 282; Verhoef [31], p. 32). Therefore, it can be concluded, that available empirical studies provide mixed support for loyalty programs, and there is still much controversy over whether the loyalty program is an appealing marketing tool. Results of loyalty programs, made by companies on the Polish market illustrated in Table 5. One of the main variables that describe the capacity of existing loyalty programs to produce a set of desired effects is the loyalty program effectiveness rating. The focal variable of such rating used in studies that compare loyalty programs across competitors (multiple company) is share of wallet (SOW), which describes:

- amount of the customer's total spending that a firm captures in the products or services that it offers,

- increase or decrease in market share that is being recorded by a firm over a set period of time.
Studies conducted in 2003 (Magi [23], p. 98) using consumer panel data of grocery purchases find mixed support for the positive effect of loyalty programs on share of wallet. Discussed studies reveal increased share of wallet for four of seven analysed programs and offers support for the use of accumulated rewards in loyalty programs. Moreover, recorded increase in share of wallet was supported only on chain level, not at the individual store level. Similarly, the studies conducted in 2006 among French grocery retailers seem to confirm ambiguous effect of loyalty programs on retailers' profitability and their popularity among consumers (Meyer-Waarden et al. [24], p. 86).

Reviewed results of numerous studies clearly signify that loyal behaviour among consumers is triggered by a host of internal and external factors. Based on discussed studies it may also be concluded that failure to identify major loyalty drivers usually results in less than satisfactory effects of implemented loyalty scheme on a firm's key customers. For this, very reason implementation of a loyalty program, should be proceeded by extensive research into customers' needs and expectations as well as careful analysis of existing loyalty schemes and other elements of a firm's external environment. It is important to note, that available research data tends to focus on short-term effectiveness of loyalty programs, and their long-term effects on consumers as well as competitors remain largely unstudied. This clearly signifies an existing knowledge gap in the field of loyalty building activities and justifies the need to conduct further research into:

- detailed characteristics of customer segments enrolled in loyalty programs,

- key factors that affect loyalty program effectiveness, 
- types and levels of costs associated with loyalty program preparation, implementations and maintenance,

- general effectiveness of existing loyalty programs.

Due to prevalent use of loyalty programs in recent years and the role they play in everyday practice of marketing management, such studies should be conducted in both, B2C and B2B markets.

\section{Conclusions}

Loyalty programs are viewed as one of the key elements and one of the key tools of a firm's customer relationship management system. Preparation, implementation and maintenance of a loyalty program generate significant costs, and therefore should be approached as long - term commitment and an integral part of a long - term marketing strategy. Numerous companies, especially in the markets, which are saturated with similar loyalty schemes, perceive the implementation of such programs as part of their defensive strategy, which helps to retain most valued customers and creates considerable barriers against customers' switching suppliers. Viewing loyalty program as an instrument of defensive marketing strategy usually results in a costly investment, which fails to fulfil its potential and impact the profitability of a business. The empirical studies reviewed in the article seem to confirm, that most loyalty programs are devised as reactive measures and their authors fail to consider a host of factors that may affect the effectiveness of the scheme in its operative stages.

Failure to analyse the entire market (i.e. consumers and competition) in the development stages of loyalty program preparation results in a scheme that lacks expected effectiveness and adds to general disappointment with commonly used relationship marketing techniques. Therefore, it can be concluded that a newly devised loyalty program should provide any business with two key benefits:

- competitive benefit - a loyalty program should be viewed as an element of firm's most valuable assets, which plays a major part in building long-term competitive advantage,

- value benefit - a loyalty program aids a firm's data mining capabilities and therefore should help with providing customers with desired value.
From the customer's viewpoint, a loyalty program provides a host of unique, tangible and intangible benefits (e.g.: discounts, rewards, gifts) and so can be wrongly perceived as a self - sufficient entity, which in the case of improperly devised schemes results in fostering loyalty toward the program rather than a particular brand or firm. Furthermore, in markets saturated with similar loyalty programs such scenario may lead to fostering loyalty toward rewards offered by the scheme and erosion of existing, true loyalty toward any particular brand or firm. In order to prevent further disappointment with the effectiveness of loyalty programs, marketers should adopt a new approach to loyalty scheme development. It is important to recognize that loyalty programs do not operate as separate entities in an isolated environment, and so their development, should be preceded, by careful examination of existing loyalty schemes run, by direct competitors as well as customers' needs and expectations.

\section{$8 \quad$ References}

[1] Allaway A.W., Gooner R.M., Berkowitz D., Davis L. - Deriving and Exploring Behaviour Segments Within a Retail Loyalty Card Program. European Journal of Marketing, Vol. 40, No. 11-12, 2006.

[2] Blattberg R.C., Gett G., Thomas J.S. - Klient jako kapitat. MT Biznes, Warszawa 2004.

[3] Bloemer J., de Ruyter K. - On the Relationship of Store Image, Store Satisfactions and Store Loyalty [in] European Journal of Marketing, Vol 32, No 5/6, 1998.

[4] Bolton R.N., Kannan P.K., Bramlett M.D. Implications of Loyalty Program Membership and Service Experiences for Customer Retention and Value [in] Journal of the Academy of Marketing Science, Vol. 28, No.1, 2000.

[5] Dębski M. - Kreowanie silnej marki. WN PWE, Warszawa 2009.

[6] Dobiegała-Korona B. - Wartość dla klientów generatorem wartości przedsiębiorstwa [in] Współczesne źródła wartości przedsiębiorstwa (ed. Dobiegała -Korona B., Herman A.), Difin, Warszawa 2006.

[7] Dowling G., Uncles M. - Do Customer Loyalty Programs Really Work? [in] Sloan Management Review, Vol. 38, No. 4, 1997.

[8] Falkowski A., Tyszka T. - Psychologia zachowań konsumenckich. GWP, Gdańsk 2009. 
[9] Ferguson R., Hlavinka K. - Quo Vadis: Sizing Up the U.S. Loyalty Marketing Industry. Colloquy, April 2007.

[10] Garbarski L., Rutkowski I., Wrzosek W. - Marketing. Punkt zwrotny nowoczesnej firmy, WN PWE, Warszawa 2001.

[11] Kivetz R. - Promotion Reactance: The Role of Effort-Reward Congruit [in] Journal of Consumer Research, Vol. 31, No. 4, 2005.

[12] Kołczyński J. - Zarzqdzanie relacjami z klientami na przykładzie banku [in] Wycena i zarządzanie wartością firmy (ed. Szablewski A., Tuzimek R.), Poltext, Warszawa 2005.

[13] Kopalle P.K., Neslin S.A., The Economic Viability of Frequent Reward Programs in a Strategic Competitive Environment [in] Review of Marketing Science, No. 1, 2003.

[14] Kumar V., Shah D. - Building and Sustaining Profitable Customer Loyality for the 21st Century [in] Journal of Retailing, No. 80 (4), 2004.

[15] Kwiatek P. - Programy lojalnościowe. Wolters Kluwer, Kraków 2007.

[16] Kwiatek P., Waśkowski Z. - Marketing relacji [in] Kompendium wiedzy o marketingu (ed. Mruk H., Pilarczyk B.), Warszawa 2006.

[17] Lal R., Bell D.E. - The Impact of Frequent Shopper Programs in Grocery Retailing [in] Quantitative Marketing and Economics, Vol. 1, No. 2, 2003.

[18] Leenheer J., Bijmolt T.H.A. - Which Retailers Adopt a Loyalty Program? An Empirical Study [in] Journal of Retailing and Consumer Services, Vol. 15, No. 6, 2008.

[19] Lemon K.N., Barnett-White T., Winer R.S. - Dynamic Customer Relationship Management: Incorporating Future Considerations into the Service Retention Decision [in] Journal of Marketing, Vol. 66, No. 1, 2002.

[20] Lewis M. - The Influence of Loyalty Programs and Short-Term Promotions on Customer Retention [in] Journal of Marketing Research, No. 41, 2004.

[21] Liu Y. - The Long-Term Impact of Loyalty Programs on Consumer Purchase Behaviour and Loyalty [in] Journal of Marketing, Vol. 71, No. 4, 2007.

[22] Liu Y., Yang R. - Competing Loyalty Programs: Impact of Market Saturation, Market Share and Category Expandability [in] Journal of Marketing, Vol. 73, No. 1, 2009.
[23] Mägi A.W. - Share of Wallet in Retailing: The Effects of Customer Satisfaction, Loyalty Cards and Shopper Characteristics [in] Journal of Retailing, Vol. 79, No. 2, 2003.

[24] Meyer-Waarden L., Benavent C. - The Impact of Loyalty Programmes on Repeat Purchase Behaviour [in] Journal of Marketing Management, No. 22, 2006.

[25] Rudawska E. - Lojalność klientów. PWE, Warszawa 2005.

[26] Sheth J.N., Parvatiyar A. - Relationship Marketing in Consumer Markets: Antecedents and Consequences [in] Journal of the Academy of Marketing Science, No. 23, 1995.

[27] Simonson I. - Earning the Right to Indulge: Effort as a Determinant of Customer Preferences Toward Frequency Program Rewards [in] Journal of Marketing Research, No. 39, 2002.

[28] Sirdeshmukh D, Singh J., Sabol B. - Consumer, Trust, Value, and Loyalty in Relational Exchanges [in] Journal of Marketing, Vol. 66, No. 1, 2002.

[29] Taylor G.A., Neslin S.A. - The Current and Future Sales Impact of a Retail Frequency Rewards Program [in] Journal of Retailing, Vol. 84, No. 4, 2005.

[30] Urban W., Siemieniako D. - Lojalność klientów. Modele, motywacja i pomiar. Wydawnictwo Naukowe PWN, Warszawa 2008.

[31] Verhoef P.C. - Understanding the Effect of Customer Relationship Management Efforts on Customer Retention and Customer Share Development [in] Journal of Marketing, Vol. 67, No. 4, 2003.

[32] Woodruff R.B. - Customer Value: The Next Source for Competitive Advantage [in] Journal of the Academy of Marketing Science, No. 25, 1997.

[33] http://iclployalty.com/homePage?q=customerloyalty (accessed on 18.10.2010)

[34] Yi Y., Jeon H. - Effects of Loyalty Programs on Value Perception, Program Loyalty, and Brand Loyalty [in] Journal of the Academy of Marketing Science, Vol. 31, No. 3, 2003. 